\title{
Pengembangan Usaha Ternak Sapi Perah : Evaluasi Konteks Kerentanan Dan Dinamika Kelompok
}

Business Development of Fairy Cattle : Evaluation of Vulnerability Context and Group Dynamics

\author{
Amam Amam ${ }^{1,2)}$ dan Pradiptya Ayu Harsita1) \\ 1)Program Studi Peternakan, 2)Program Studi Agribisnis, Fakultas Pertanian, \\ Universitas Jember, Jalan Kalimantan No. 37 Jember, Jawa Timur 68121 \\ Indonesia. Email : amam.faperta@unej.ac.id
}

\begin{abstract}
Intisari
Usaha ternak sapi perah dalam mendukung pembangunan pertanian subsektor peternakan mempunyai nilai strategis untuk memenuhi kebutuhan sumber pangan asal ternak yaitu susu yang terus meningkat sebagai akibat dari pertumbuhan jumlah penduduk. Produksi susu dalam negeri hanya mampu terpenuhi $21 \%$ dari konsumsi nasional, sedangkan sisanya sebesar $79 \%$ dipasok dari impor. Tujuan penelitian yaitu menemukan model pengembangan usaha ternak sapi perah berdasarkan konteks kerentanan dan dinamika kelompok. Jumlah sampel penelitian sebanyak 119 peternak sapi perah. Analisis data menggunakan SEM (Strutural Equation Model) dengan SmartPLS 2.0. Hasil penelitian yaitu: a) konteks kerentanan berpengaruh negatif secara signifikan terhadap pengembangan usaha ternak sapi perah, $b$ ) dinamika kelompok berpengaruh positif secara signifikan terhadap pengembangan usaha ternak sapi perah, dan c) konteks kerentanan berpengaruh negatif secara signifikan terhadap dinamika kelompok peternak sapi perah.

Kata kunci: aspek kerentanan, dinamika kelompok, kelembagaan, pengembangan usaha, dan sapi perah.
\end{abstract}

\begin{abstract}
The dairy cattle farming to supporting the agricultural development of the livestock subsector has strategic value to necessary demand of food animal source that is milk which is always increase as a result of population growth. Domestic milk production is only $21 \%$ of national consumption, while the remaining $79 \%$ is supplied from imports. The research objective was to find a model for developing dairy cattle business based on the context of vulnerability and group dynamics. The number of research sample is 119 dairy cattle farmers. Data analysis using SEM (Strutural Equation Model) with SmartPLS 2.0. The results of the research are: 1) the vulnerability context has significant negative effect on the development of dairy cattle farming, 2) the group dynamics has a significant positive effect on the development of dairy cattle farming, and 3 ) the vulnerability context significantly negative effect the group dynamics of dairy cattle farmer.

Keywords: vulnerability aspect, group dynamics, institutional, farming development, and dairy cattle.

\section{Pendahuluan}

Usaha ternak sapi perah dalam mendukung pembangunan pertanian subsektor peternakan mempunyai nilai strategis untuk memenuhi kebutuhan pangan asal ternak yaitu susu yang terus meningkat sebagai akibat dari pertumbuhan jumlah penduduk.

Produksi susu dalam negeri hanya mampu terpenuhi $21 \%$ dari konsumsi nasional, sedangkan sisanya sebesar 79\% dipasok dari impor (Kementerian Pertanian, 2016).

Dampak dari tingginya impor susu mengakibatkan timbulnya kerugian langsung yang dirasakan
\end{abstract}


oleh peternak sapi perah Indonesia. Impor susu juga mengakibatkan berkurangnya devisa negara, sehingga peran pemerintah dan daya dukung stakeholder diharapkan mampu untuk meningkatkan pertumbuhan dan produktivitas sapi perah nasional.

Usaha ternak sapi perah di Indonesia tidak terlepas dari berbagai masalah, baik secara teknis maupun nonteknis. Konteks kerentanan sebagai aspek risiko bisnis usaha ternak sapi perah yang selama ini masih menjadi momok menakutkan bagi peternak sapi perah diantaranya adalah: 1) musim merupakan kondisi alam yang tidak menentu, 2) keamanan merupakan tingkat pencurian ternak, 3) penyakit ternak, 4) fluktuasi harga susu nasional dan daerah, 5) kebijakan pemerintah, 6) kebijakan kelompok peternak atau kelembagaan peternak, dan 7) moralitas kelompok peternak (Syukur, 2014).

Moralitas kelompok peternak menentukan performa dinamika kelompok peternak sebagai suatu bentuk kelembagaan. Dinamika kelompok peternak dipengaruhi oleh: 1) sarana kelompok peternak, 2) pencapaian tujuan kelompok peternak, 3) fungsi dan tugas kelompok peternak, 4) struktur kelompok peternak, 5) kerukunan kelompok peternak, dan 6) bentuk kelembagaan kelompok peternak.

Bentuk kelembagaan peternak dapat mempengaruhi pengembangan usaha ternak sapi perah di Indonesia. Keberhasilan pengembangan usaha ternak diantaranya yaitu: 1) bertambahnya pendapatan peternak, 2) bertambahnya popu- lasi ternak yang dipelihara, 3) bertambahnya tenaga kerja yang dibayar, dan 4) bertambahnya unit produksi atau kandang ternak.

Pengembangan usaha ternak sapi perah dalam mendukung pembangunan nasional sesuai dengan: 1) RPJMN 2015-2019, 2) Permentan No. 100 tahun 2014, 3) Renstra Nasional tahun 2015-2019, dan 4) Permentan No. 55 tahun 2006.

Penelitian bertujuan untuk: 1) merumuskan pengaruh konteks kerentanan terhadap pengembangan usaha ternak sapi perah, 2) merumuskan pengaruh dinamika kelompok terhadap pengembangan usaha ternak sapi perah, dan 3) merumuskan pengaruh konteks kerentanan terhadap dimanika kelompok.

\section{Metode Penelitian}

Penelitian dilakukan bulan Februari sampai April 2018. Lokasi penelitian dipilih secara purposive di Kecamatan Pujon Kabupaten Malang. Lokasi tersebut dipilih dengan pertimbangan bahwa jumlah peternak yang ada di Kecamatan Pujon sebanyak 5.527 orang dengan jumlah populasi sapi perah sebanyak 18.374 ekor. Jumlah tersebut terdiri dari induk bunting sebanyak 3.134 ekor, induk tidak bunting sebanyak 5.413 ekor, dan induk kering sebanyak 1.281 ekor, dara bunting sebanyak 1.198 ekor, dara tidak bunting sebanyak 2.125 ekor, pedet jantan sebanyak 3.154 ekor, dan pedet betina sebanyak 1.716 ekor (Kopsae, 2018). Kecamatan Pujon merupakan kecamatan dengan jumlah populasi sapi perah terbanyak di Jawa Timur. 


\section{Variabel Penelitian}

Penelitian ini terdiri dari 3 variabel manifest dan 17 indikator. Variabel tersebut yaitu:

Tabel 1. Variabel dan Indikator

\begin{tabular}{|c|c|}
\hline $\begin{array}{l}\text { Indikator } \\
\text { Kerentanan }\left(X_{1}\right)\end{array}$ & Notasi \\
\hline $\begin{array}{l}\text { musim (kondisi tidak } \\
\text { normal) }\end{array}$ & $\mathrm{X}_{1.1}$ \\
\hline $\begin{array}{l}\text { keamanan (tingkat pencurian } \\
\text { ternak) }\end{array}$ & $\mathrm{X}_{1.2}$ \\
\hline penyakit ternak & $\mathrm{X}_{1.3}$ \\
\hline fluktuasi harga susu & $\mathrm{X}_{1.4}$ \\
\hline kebijakan pemerintah & $X_{1.5}$ \\
\hline $\begin{array}{l}\text { kebijakan kelompok } \\
\text { peternak (kelembagaan } \\
\text { peternak) }\end{array}$ & $\mathrm{X}_{1.6}$ \\
\hline $\begin{array}{l}\text { moralitas peternak dalam } \\
\text { kelompok }\end{array}$ & $\mathrm{X}_{1.7}$ \\
\hline $\begin{array}{ll}\text { Indikator } & \text { Dinamika } \\
\text { Kelompok }\left(\mathrm{Z}_{1}\right) & \\
\end{array}$ & Notasi \\
\hline sarana kelompok peternak & $\mathrm{Z}_{1.1}$ \\
\hline capaian tujuan kelompok & $\mathrm{Z}_{1.2}$ \\
\hline fungsi dan tugas kelompok & $\mathrm{Z}_{1.3}$ \\
\hline struktur kelompok & $\mathrm{Z}_{1.4}$ \\
\hline kerukunan kelompok & $\mathrm{Z}_{1.5}$ \\
\hline $\begin{array}{l}\text { bentuk kelembagaan } \\
\text { kelompok }\end{array}$ & $\mathrm{Z}_{1.6}$ \\
\hline $\begin{array}{ll}\text { Indikator } & \text { Pengembangan } \\
\text { Usaha }\left(Y_{1}\right) & \end{array}$ & Notasi \\
\hline bertambahnya pendapatan & $\mathrm{Y}_{1.1}$ \\
\hline bertambahnya populasi & $\mathrm{Y}_{1.2}$ \\
\hline bertambahnya tenaga kerja & $\mathrm{Y}_{1.3}$ \\
\hline $\begin{array}{l}\text { bertambahnya unit produksi } \\
\text { (kandang) }\end{array}$ & $\mathrm{Y}_{1.4}$ \\
\hline
\end{tabular}

\section{Populasi Penelitian}

Perhitungan sampel berdasarkan teori Amora yaitu 5-10 kali jumlah variabel yang digunakan dalam penelitian. Jumlah sampel yang digunakan dalam penelitian ialah 51 variabel, yang teridiri dari:

a) konteks kerentanan usaha ternak sapi perah, b) dinamika kelompok peternak sapi perah, dan c) pengembangan usaha ternak sapi perah. Berdasarkan teori Amora, sampel yang digunakan dalam penelitian yaitu:

$$
17 \text { variabel } X 7=119 \text { sampel }
$$

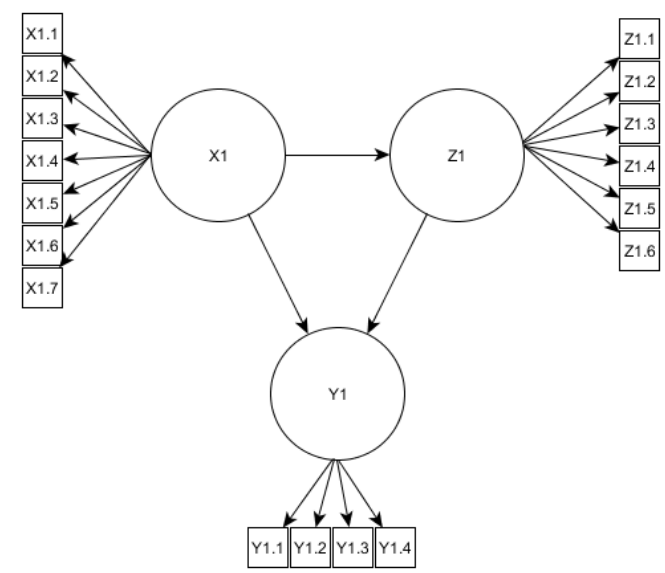

Gambar 1. Model Hubungan Variabel

\section{Pengumpulan Data}

Data diperoleh dari kuisioner dengan skala likert yang diberikan kepada responden, metode wawancara dan pengamatan langsung digunakan untuk mengetahui dan mengukur indikator dan variabel. Jenis data dibagi menjadi data primer dan data sekunder. Data primer didapat langsung dari responden, sedangkan data sekunder diperoleh dari arsip data di Koperasi SAE Pujon, data di Kecamatan Pujon, data BPS, data Dinas Peternakan Kabupaten Malang, dan data lain yang mendukung penelitian.

\section{Analisis Data}

SEM (Structural Equation Model) digunakan untuk menjawab hipotesis 1 dan 2, yaitu pengaruh konteks kerentanan $\left(X_{1}\right)$ terhadap pengembangan usaha ternak $\left(\mathrm{Y}_{1}\right)$ dan pengaruh dinamika kelompok peternak $\left(Z_{1}\right)$ terhadap pengembangan usaha ternak $\left(\mathrm{Y}_{1}\right)$. Analisis 
SEM menggunakan aplikasi SmartPLS 2.0. Penggunaan SEM juga dapat mengetahui hubungan antar-variabel, sehingga mempermudah peneliti dalam menemukan teori baru atau memperkuat teori yang lemah (Wiyono, 2012).

\section{Hasil Penelitian}

\section{Uji Indikator}

Indikator pendukung variabel utama diuji menggunakan Smart PLS 2.0 dan didapatkan hasil sebagai berikut (Tabel 2):

Tabel 2. Nilai Outer Loadings

\begin{tabular}{ccccc}
\hline & $\mathrm{X}_{1}$ & $\mathrm{Z}_{1}$ & $\mathrm{Y}_{1}$ & Result \\
\hline $\mathrm{X}_{1.1}$ & -0.225 & & & - \\
$\mathrm{X}_{1.2}$ & -0.077 & & & - \\
$\mathrm{X}_{1.3}$ & -0.179 & & & - \\
$\mathrm{X}_{1.4}$ & 0.789 & & & Valid \\
$\mathrm{X}_{1.5}$ & 0.760 & & & Valid \\
$\mathrm{X}_{1.6}$ & 0.849 & & & Valid \\
$\mathrm{X}_{1.7}$ & 0.757 & & & Valid \\
$\mathrm{Z}_{1.1}$ & & 0.550 & & Valid \\
$\mathrm{Z}_{1.2}$ & & 0.745 & & Valid \\
$\mathrm{Z}_{1.3}$ & & 0.863 & & Valid \\
$\mathrm{Z}_{1.4}$ & & 0.752 & & Valid \\
$\mathrm{Z}_{1.5}$ & & -0.502 & & - \\
$\mathrm{Z}_{1.6}$ & & 0.393 & & - \\
$\mathrm{Y}_{1.1}$ & & & 0.315 & - \\
$\mathrm{Y}_{1.2}$ & & & 0.380 & - \\
$\mathrm{Y}_{1.3}$ & & & 0.667 & Valid \\
$\mathrm{Y}_{1.4}$ & & & 0.830 & Valid \\
\hline
\end{tabular}

Sumber: Data diolah (2018)

Nilai Outer Loadings yang memenuhi syarat yaitu lebih dari 0.500. Data Tabel 2 menunjukkan bahwa hasil uji indikator variabel konteks kerentanan yang memenuhi syarat yaitu: a) fluktuasi harga susu, b) kebijakan pemerintah, c) kebijakan kelompok peternak atau kelembagaan peternak, dan d) moralitas peternak dalam kelompok.

Hasil uji indikator variabel dinamika kelompok yang

memenuhi syarat yaitu: a) sarana kelompok peternak, b) capaian tujuan kelompok, c) fungsi dan tugas kelompok, dan d) bentuk kelembagaan kelompok. Hasil uji indikator variabel pengembangan usaha yang memenuhi syarat ialah: a) bertambahnya tenaga kerja yang dibayar dan b) bertambahnya unit produksi atau kandang.

\section{Uji Struktural}

Uji struktural terdiri dari nilai Composite Reliability (CR), nilai $\mathrm{R}$ Square $\left(\mathrm{R}^{2}\right)$, dan nilai Cronbach's Alpha (CA), masing-masing nilai tersebut (Tabel 3) yaitu:

Tabel 3. Uji Struktural

\begin{tabular}{clcc}
\hline & CR & $\mathrm{R}^{2}$ & $\mathrm{CA}$ \\
\hline $\mathrm{X}_{1}$ & 0.618 & & 0.598 \\
$\mathrm{Z}_{1}$ & 0.696 & 0.261 & 0.553 \\
$\mathrm{Y}_{1}$ & 0.647 & 0.266 & 0.564 \\
\hline \multicolumn{4}{c}{ Sumber: Data diolah (2018) } \\
Uji & struktural pada & uji
\end{tabular}
pengaruh atau uji hipotesis setelah uji indikator terdiri dari nilai koefisien determinasi $\left(\mathrm{R}^{2}\right)$, nilai $\mathrm{t}$ statistik, dan nilai koefisien parameter, masing-masing nilai tersebut (Tabel 4) yaitu:

Tabel 4. Uji Model

\begin{tabular}{lr}
\hline \multicolumn{1}{c}{ Pengujian } & Hasil Uji \\
Koefisien Determinasi $\mathrm{R}^{2}$ & \\
Dinamika Kelompok & 0.185 \\
Pengembangan Usaha & 0.231 \\
\hline T-statistik & \\
$\mathrm{X}_{1} \rightarrow \mathrm{Y}_{1}$ & 3.041 \\
$\mathrm{Z}_{1} \rightarrow \mathrm{Y}_{1}$ & 4.747 \\
$\mathrm{X}_{1} \rightarrow \mathrm{Z}_{1}$ & 6.810 \\
\hline Koefisien Parameter & \\
$\mathrm{X}_{1} \rightarrow \mathrm{Y}_{1}$ & -0.207 \\
$\mathrm{Z}_{1} \rightarrow \mathrm{Y}_{1}$ & 0.353 \\
$\mathrm{X}_{1} \rightarrow \mathrm{Z}_{1}$ & -0.429 \\
\hline Sumber: Data diolah (2018) &
\end{tabular}




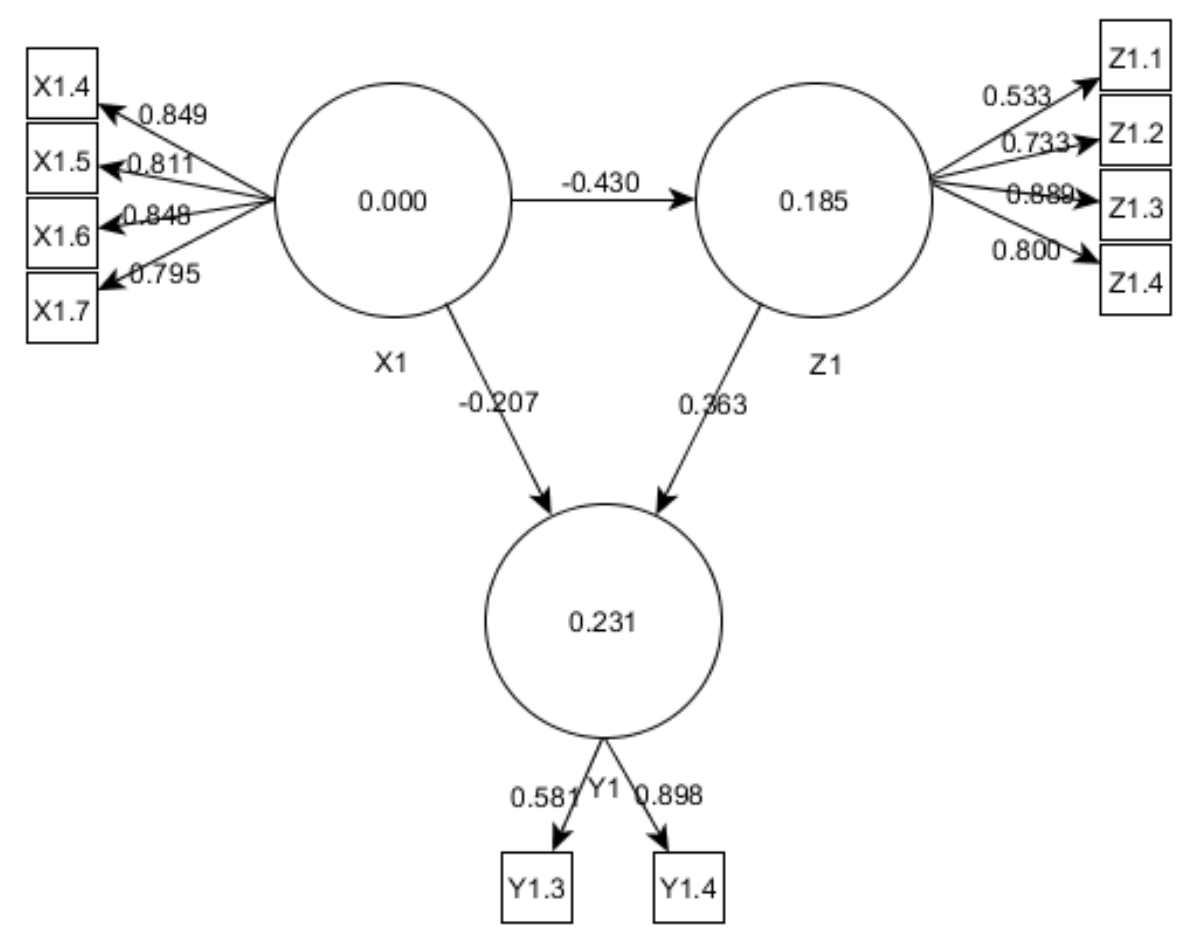

Gambar 2. Hasil Algoritma PLS

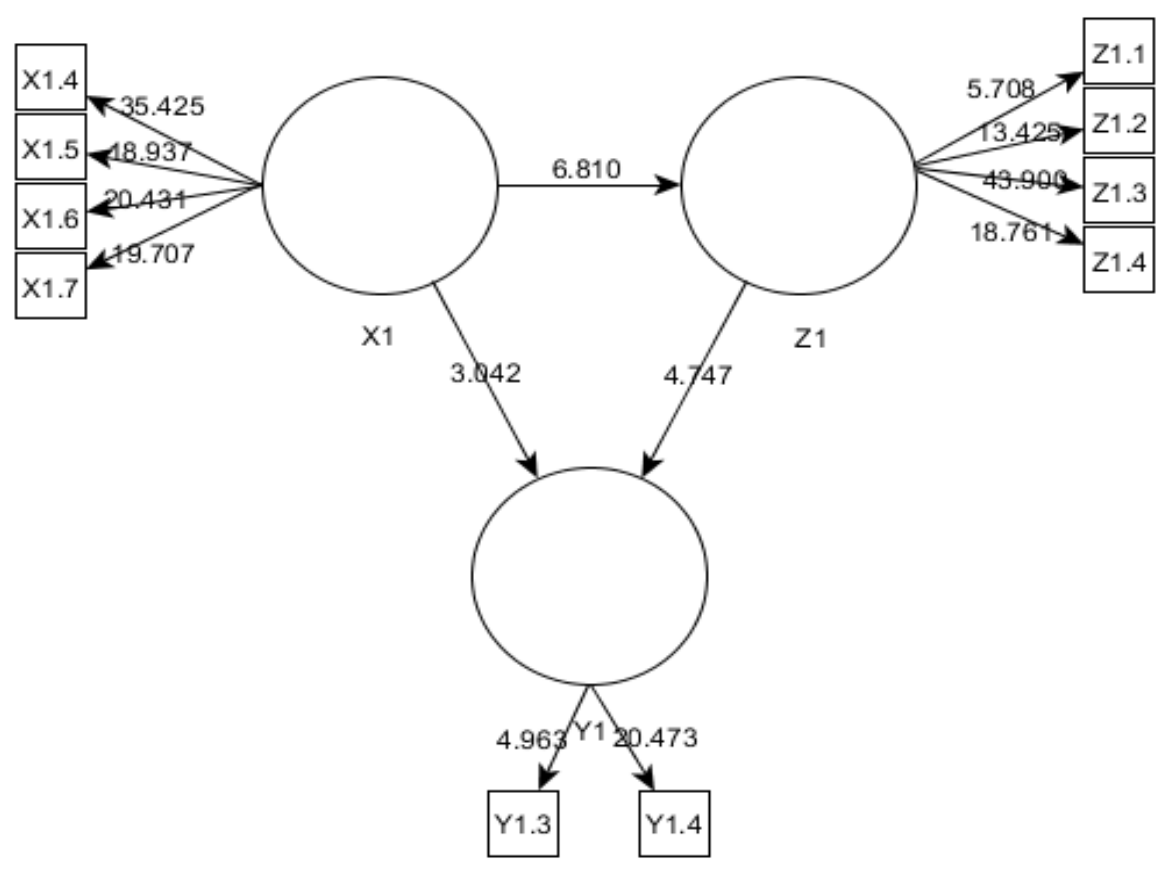

$\mathrm{t}$ tabel $=1.657$

Gambar 3. Hasil Bootstraping PLS

\section{Pembahasan}

\section{Umur Peternak}

Umur peternak (Tabel 4)dibagi menjadi lima kategori, yaitu: a) peternak dengan umur di bawah 30 tahun, b) peternak dengan umur 30-40 tahun, c) peternak dengan umur 40-50 tahun, d) peternak dengan umur 50-60 tahun, dan e) peternak dengan umur di atas 60 tahun. 


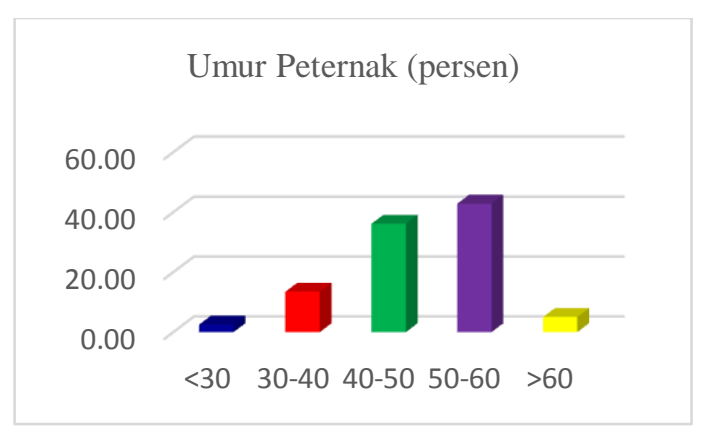

Gambar 4. Umur Peternak

Peternak sapi perah di Kecamatan Pujon Kabupaten Malang masih didominasi oleh peternak tua dengan umur 40-50 sebanyak $36,13 \%$ dan umur $50-60$ sebanyak $42,86 \%$. Umur peternak sapi perah berbanding lurus dengan pengalaman peternak dalam beternak sapi perah. Hal tersebut terjadi karena rata-rata peternak mengusahakan sapi perah secara turun temurun yang dilakukan oleh antar-generasi, sehingga keberlanjutan usaha ternak sapi perah tetap terjaga sampai sekarang.

\section{Pendidikan Peternak}

Pendidikan peternak (Gambar 5) dibagi menjadi empat kategori, yaitu: a) Sekolah Dasar (SD), b) Sekolah Menengah Pertama (SMP), c) Sekolah Menengah Atas (SMA), dan d) Perguruan Tinggi (PT).

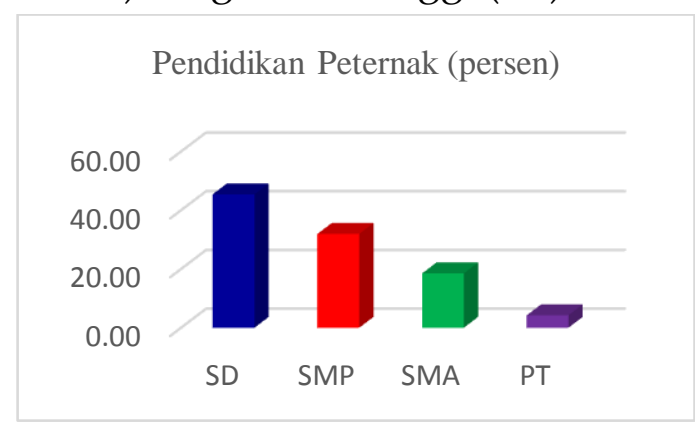

Gambar 5. Pendidikan Peternak

Tingkat pendidikan peternak sapi perah di Kecamatan Pujon Kabupaten Malang terbilang masih rendah. Dominasi peternak yang hanya lulusan SD mencapai 45,38\%. Hal tersebut menunjukkan anggapan masyarakat bahwa menjadi peternak sapi perah tidak harus mempunyai pendidikan yang tinggi, peternak hanya membutuhkan keterampilan yang sejatinya bisa diwariskan orang tua kepada anak-anaknya.

\section{Pengalaman Beternak}

Pengalaman beternak sapi perah (Gambar 6) dibagi menjadi lima kategori, yaitu: a) pengalaman beternak kurang dari lima tahun, $b$ ) pengalaman beternak 5-10 tahun, c) pengalaman beternak 10-15 tahun, d) pengalaman beternak 15-20 tahun, dan e) pengalaman beternak lebih dari 20 tahun.

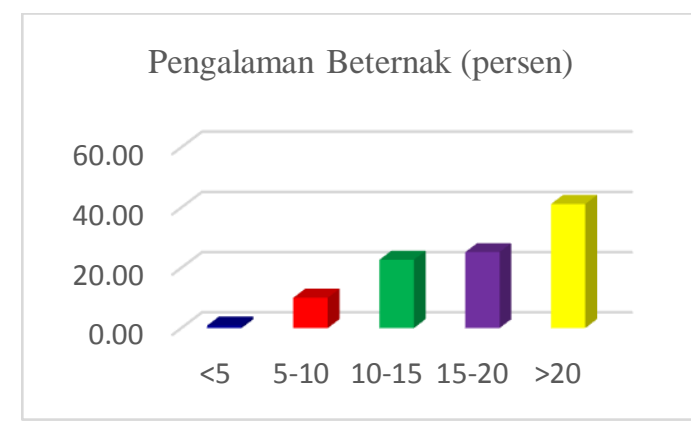

Gambar 6. Pengalaman Beternak

Pengalaman peternak dalam beternak sapi perah di Kecamatan Pujon Kabupaten Malang mayoritas telah dilakukan secara turun menurun. Hal tersebut ditunjukkan oleh tingginya pengalaman peternak dalam beternak sapi perah yang lebih dari 20 tahun, yaitu mencapai 41,18\%.

\section{Jumlah Kepemilikan Ternak}

Jumlah ternak yang dipelihara peternak (Gambar 7) dibagi menjadi lima kategori, yaitu a) kepemilikan sapi kurang dari 3 ekor, b) kepemilikan sapi 3-6 ekor, c) kepe-milikan sapi 6-9 ekor, d) 
kepemilikan sapi 9-12 ekor, dan e) kepemilikan sapi lebih dari 12 ekor.

Jumlah KepemilikanTernak (persen)

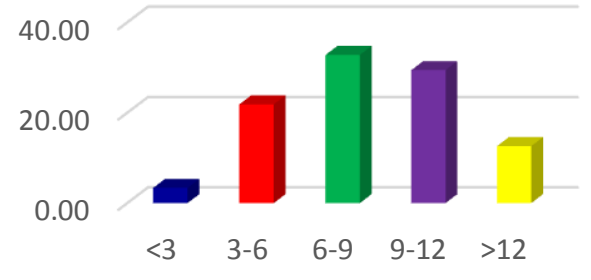

Gambar 7. Jumlah Kepemilikan Ternak

Jumlah sapi perah yang dipelihara peternak di Kecamatan Pujon Kabupaten Malang rata-rata 8 ekor per peternak. Hal tersebut ditunjukkan oleh tingginya persentase kepemilikan ternak dengan jumlah 6-9 ekor yang mencapai $32,77 \%$. Peternak yang mengusahakan sapi perah di Kecamatan Pujon Kabupaten Malang jarang sekali menjual ternaknya, kecuali jenis kelamin jantan yang difungsikan sebagai ternak pedaging dan sapi perah betina yang sudah afkir dengan produksi susu yang sangat rendah di bawah tiga liter per hari.

\section{Pengaruh Konteks Kerentanan terhadap Pengembangan Usaha}

Konteks kerentanan terdiri dari: 1) fluktuasi harga susu, 2) kebijakan pemerintah, 3) kebijakan kelompok peternak atau kelembagaan peternak, dan 4) moralitas peternak dalam kelompok. Konteks kerentanan tersebut berpengaruh negatif secara signifikan terhadap pengembangan usaha ternak sapi perah di Kecamatan Pujon Kabupaten Malang, sehingga munculnya risiko yang disebabkan konteks kerentanan tersebut berdampak pada tidak bertambahnya jumlah tenaga kerja yang dibayar dan tidak betambahnya unit produksi atau kandang. Hal tersebut menunjukkan hasil uji SEM dengan SmartPLS 2.0 membuktikan bahwa hipotesis pertama diterima.

Konteks kerentanan mempunyai pengaruh negatif pada pengembangan usaha ternak sapi perah. Raharto (2010) dalam konteks risiko bisnis menyatakan bahwa faktor yang mempengaruhi nilai tukar petani/peternak ialah umur dan status kepemilikan lahan. Kelembagaan petani/ peternak belum menunjukkan adanya kerjasama antara kelompok tani/peternak, KUD, serta lembaga keuangan. Dampaknya yaitu kelompok tani/ternak dan KUD tidak dapat melakukan perannya dalam membeli hasil pertanian karena terbatasnya modal, sehingga pihak swasta lebih bisa berperan dalam membeli hasil pertanian/ peternakan. Hal tersebut mengakibatkan adanya penurunan kepercayaan petani/peternak terhadap kinerja KUD ataupun kelembagaan tani/peternak, padahal menurut Fitriani (2015) menjelaskan bahwa kondisi prasyarat bekerjanya suatu koperasi ialah performa manajerial keuangan dan organisasi koperasi, namun kenyataannya menurut Arimbawa (2013) yaitu kelompok tani/peternak, penyuluh, dan lembaga keuangan yang dirasakan petani/peternak kurang berperan dalam proses usaha tani/ peternak.

Permasalahan yang merupakan risiko bisnis pada kelembagaan rantai pasok menurut Rahayu dan Kartika (2015) diantaranya ialah: a) hasil 
penelitian yang telah dilakukan tidak diimplementasikan secara berkelanjutan, b) kemitraan bisnis tidak berjalan dengan baik, c) banyak pedagang tidak membayar sesuai dengan kesepakatan karena bentuk pembayaran biaya secara cicilan (Abubakar dkk, 2013), sedangkan keberadaan fasilitas irigasi tidak berpengaruh nyata terhadap penurunan kemiskinan petani/peternak (Nashwari dkk, 2016).

Mardiana dkk (2011) berkaitan dengan pengembangan usaha menyatakan bahwa peningkatan difusi dan adopsi teknologi oleh petani/ peternak perlu memperhatikan beberapa hal, yaitu: a) perbaikan teknologi produksi bibit, b) peningkatakan kapasitas kelembagaan tani/ peternak dalam pengembangan agribisnis, dan c) pengembangan jaringan komunikasi dan kerjasama dalam produksi dan pemasaran benih berkualitas.

Yudiarini (2017) menyatakan bahwa cara untuk mewujudkan program pertanian komersial ialah: a) peningkatan perilaku (pengetahuan, sikap, dan keterampilan) petani terhadap inovasi teknologi baru, b) pemberian bantuan sarana (input) berupa subsidi, c) dukungan modal usaha tani/ternak, d) pengembangan teknologi baru, e) per-baikan kelembagaan pertanian/ peternakan, f) penyediaan sarana transportasi, dan g) penyediaan pasar. Hal tersebut ditanggapi oleh Ali dkk (2018) yang menyatakan bahwa perubahan kelembagaan usaha tani/ternak berlangsung dari subsisten ke komersial serta dari penguasaan sumber daya dan aktivitas rumah tangga menjadi terbuka di luar rumah tangga petani/ peternak. Perubahan tersebut dipicu oleh inovasi dan penggunaan teknologi pertanian/ peternakan yang telah membuka lapangan kerja dan usaha baru dengan relasi yang saling berkaitan dengan usaha tani/ternak.

Dinamika kelompok dipengaruhi oleh konteks kerentanan sebesar 0.185 atau sebesar $18,5 \%$, sedangkan sisanya sebesar $81,5 \%$ dipengaruhi oleh faktor lain yang tidak terdapat di dalam model. Semua pengaruh dari variabel eksogen dan endogen terhadap variabel endogen dinyatakan signifikan karena nilai tstatistiknya lebih tinggi dari pada $\mathrm{t}$ tabel dengan signifikansi 5\% dan DF 119 adalah sebesar 1.657. Besarnya koefisien parameter dari pengaruh konteks kerentanan terhadap pengembangan usaha sebesar -0.207, artinya terdapat pengaruh negatif dari konteks kerentanan terhadap pengembangan usaha sebesar 20,7\%. Hal tersebut menunjukkan bahwa semakin tinggi konteks kerentanan, maka semakin rendah pengembangan usaha ternak sapi perah di Kecamatan Pujon Kabupaten Malang.

\section{Pengaruh Dinamika Kelompok terhadap Pengembangan Usaha}

Dinamika kelompok terdiri dari: 1) sarana kelompok peternak, 2) capaian tujuan kelompok, 3) fungsi dan tugas kelompok, dan 4) bentuk kelembagaan kelompok. Dinamika kelompok tersebut berpengaruh positif secara signifikan terhadap pengembangan 
usaha ternak sapi perah di Kecamatan Pujon Kabupaten Malang, sehingga performa kelembagaan yang baik berdampak pada bertambahnya jumlah tenaga kerja yang dibayar dan bertambahnya unit produksi atau kandang. Hal tersebut menunjukkan hasil uji SEM dengan SmartPLS 2.0 membuktikan bahwa hipotesis kedua diterima.

Dinamika kelompok mempunyai pengaruh positif pada pengembangan usaha. Wahyuni (2017) menyatakan bahwa upaya penguatan kelembagaan petani/ peternak memerlukan dukungan dari seluruh pihak, sehingga pembinaan dan pendampingan kelompok tani/ peternak bisa dilakukan oleh Penyuluh Pertanian Lapangan (PPL), atau organisasi lain yang dianggap mampu untuk melibatkan dalam usaha penguatan kelompok petani/ peternak dalam permberdayaan (Ramdhani dkk. 2012) yang mampu memberikan kekuatan bagi petani/peternak dan berdampak pada kesejahteraan petani/ peternak dan masyarakat (Nasrul, 2012).

Anantanyu (2011) menjelaskan bahwa keberadaan kelembagaan petani/peternak sudah menjadi keniscayaan supaya memperbaiki taraf hidup, harkat, dan martabat petani/peternak Indonesia, karena keberadaan kelembagaan sekarang ini masih belum mampu meningkatkan nilai tambah produk/NTP (Djalil, 2016).

$$
\text { Kelompok tani/peternak }
$$
yang baik yaitu yang mampu menjalankan fungsinya sebagai kelas belajar, wahana untuk bekerja sama, dan sebagai unit produksi (Rustandi dan Suhadji, 2017), sehingga dinamika kelompok tani/ peternak yang baik bisa terlihat dari kuatnya faktor-faktor kekuatan yang mampu menggerakkan perilaku anggota kelompok untuk mencapai tujuan secara efektif dan efisien (Suswandi dan Sutarno, 2017).

Pengembangan usaha dipengaruhi oleh dinamika kelompok sebesar 0.231 atau sebesar $23,1 \%$, sedangkan sisanya sebesar $76,9 \%$ dipengaruhi oleh faktor lain yang tidak terdapat di dalam model. Semua pengaruh dari variabel eksogen dan endogen terhadap variabel endogen dinyatakan signifikan karena nilai t-statistiknya lebih tinggi dari pada $\mathrm{t}$ tabel dengan signifikansi $5 \%$ dan DF 119 adalah sebesar 1.657. Besarnya koefisien parameter dari pengaruh dinamika kelompok terhadap pengembangan usaha sebesar 0.353, artinya terdapat pengaruh positif dari dinamika kelompok terhadap pengembangan usaha sebesar 35,3\%. Hal tersebut menunjukkan bahwa semakin tinggi dinamika kelompok, maka semakin tinggi pula pengembangan usaha ternak sapi perah di Kecamatan Pujon Kabupaten Malang.

\section{Pengaruh Konteks Kerentanan terhadap Dinamika Kelompok}

Konteks kerentanan terdiri dari: 1) fluktuasi harga susu, 2) kebijakan pemerintah, 3) kebijakan kelompok peternak atau kelembagaan peternak, dan 4) moralitas peternak dalam kelompok. Konteks kerentanan tersebut berpengaruh negatif 
secara signifikan terhadap dinamika kelompok peternak sapi perah di Kecamatan Pujon Kabupaten Malang, sehingga munculnya risiko yang disebabkan konteks kerentanan tersebut berdampak pada tidak terpenuhinya sarana kelompok peternak, tidak tercapainya tujuan kelompok, tidak berjalannya fungsi dan tujuan kelompok, serta tidak mencerminkan bentuk kelembagaan peternak sapi perah di Kecamatan Pujon Kabupaten Malang. Hal tersebut menunjukkan hasil uji SEM dengan SmartPLS 2.0 membuktikan bahwa hipotesis ketiga diterima.

Konteks

kerentanan

mempunyai pengaruh negatif pada dinamika kelompok. Suardi dkk (2016) kelembagaan pertanian/ peternakan mempunyai potensi yang baik dalam konteks perlindungan lahan pertanian pangan dan usaha ternak, namun kurang berperan dalam upaya perlindungan lahan pertanian pangan, sehingga potensi lahan pangan semakin menurun, sehingga proses pengambilan keputusan dalam masyarakat/ petani atau peternak merupakan suatu tindakan berbasis kondisi komunitas atau disebut juga sebagai community-based action (Suradisastra, 2018).

Faktor

formal, kekosmopolitan petani/peternak, dan akses petani/ peternak terhadap tenaga profesional berkorelasi dengan manajemen kelembagaan (Yunita dkk, 2014), sehingga efektivitas kelompok merupakan keberhasilan kelompok yang membuat anggotanya loyal
(Perdana, 2016). Besarnya koefisien parameter dari pengaruh konteks kerentanan terhadap dinamika kelompok sebesar -0.430, artinya terdapat pengaruh negatif dari konteks kerentanan terhadap dinamika kelompok sebesar 43,0\%. Hal tersebut menunjukkan bahwa semakin tinggi konteks kerentanan, maka semakin rendah dinamika kelompok peternak sapi perah di Kecamatan Pujon Kabupaten Malang.

\section{Kesimpulan}

Kesimpulan penelitian pengaruh konteks kerentanan dan dinamika kelompok terhadap pengembangan usaha ternak sapi perah yaitu:

1. Konteks kerentanan berpengaruh negatif secara signifikan terhadap pengembangan usaha ternak sapi perah di Kecamatan Pujon Kabupaten Malang.

2. Dimanika kelompok berpengaruh positif secara signifikan terhadap pengembangan usaha ternak sapi perah di Kecamatan Pujon Kabupaten Malang.

3. Konteks Kerentanan berpengaruh negatif secara signifikan terhadap dinamika kelompok peternak sapi perah di Kecamatan Pujon Kabupaten Malang.

\section{Daftar Pustaka}

Abubakar, I., Yantu, M. R., dan Asih, D. N. 2013. Kinerja Kelembagaan Pemasaran Kakao Biji Tingkat Petani Perdesaan Sulawesi Tengah: Kasus Desa Ampibabo Kecamatan Ampibabo Kabu-paten Parigi Moutong. Jurnal Agrotekbis. 1 (1) : 74-80. 
Ali, M. S. S., Yunus, A., Salman, D., dan Demmallino, E. B. 2018. Rasionalitas Petani dalam Merespons Perubahan Kelembagaan Penguasaan Lahan dan Sistem Panen pada Usaha Tani Padi. Jurnal Sosial Ekonomi Pertanian. 14 (1) : 114.

Anantanyu, S. 2011. Kelembagaan Petani: Peran dan Strategi Pengembangan Kapasitasnya. Jurnal SEPA. 7 (2) : 102-109.

Arimbawa, P. 2013. Peran Kelembagaan Agribisnis dalam Usaha Tani Kakao. Jurnal Agriplus. 23 (3): 179-187.

Djalil, B. 2016. Model Penguatan Lembaga Petani sebagai Prime Mover Nilai Tambah Produk Pertanian. Jurnal Lentera. 14 (2) : 265-278.

Fitriani. 2015. Penguatan Kapasitas Kelembagaan Gapoktan melalui Pembentukan Koperasi Pertanian. Jurnal Masyarakat, Kebudayaan, dan Politik. 28 (2) 63-69.

Mardiana, Yohanes G. B., dan Irianto, B. 2011. Peran Kelembagaan Pertanian dalam Penyebaran Inovasi Teknologi Produksi Benih Kedelai di Nusa Tenggara Barat. Prosiding Seminar Hasil Penelitian Tanaman Aneka Kacang dan Umbi. 428-437.

Nashwari, I. P., Rustiadi, E., Siregar, H., dan Juanda, B. 2016. Analisis Spasial Kelembagaan Petani dan Kemiskinan Petani Tanaman Pangan Menggunakan Geographically Weighted Regression di Provinsi Jambi.
Majalah Ilmiah Globe. 18 (2) : 83-94.

Nasrul, W. 2012. Pengembangan Kelembagaan Pertanian untuk Meningkatkan Kapasitas Petani terhadap Pembangunan Pertanian. Jurnal Menara Ilmu. 3 (29) : 166-174.

Perdana, A. S. 2016. Pemberdayaan Kelompok Tani melalui Pasar Lelang sebagai Solusi Mewujudkan Kedinamisan Kesejahteraan Petani. Jurnal Ilmu Pertanian Tripoika dan Subtropika (VIGOR). 1 (1) : 52-63.

Raharto, S. 2010. Strategi Pemberdayaan Kelembagaan Petani dan Pasar Perberasan Guna Peningkatan Nilai Tukar Petani serta Ketersediaan Pangan. Jurnal Sosial Ekonomi Pertanian (JSEP). 4 (2): 83-88.

Rahayu, R. E. dan Kartika, L. 2015. Analisis Kelembagaan dan Strategi Peningkatan Daya Saing Komoditas Kentang di Kabupaten Banjarnegara, Jawa Tengah. Jurnal Ilmu Pertanian Indonesia (JIPI). 20 (2): 150-157.

Ramdhani, H., Nulhaqim, S. A., dan Fedryansah, M. 2012. Peningkatan Kesejahteraan Petani dengan Penguatan Kelompok Tani. Jurnal Riset. 2 (3) 423-429.

Rustandi, Y. dan Suhadji, R. 2017. Keragaan dan Evaluasi Fungsi Kelembagaan Kelompok Tani di Kecamatan Papar Kabupaten Kediri Jawa Timur. Jurnal Agrica Ekstensia. 11 (2) : 55-60.

Suardi, I. D. P. O., Darmawan, D. P., dan Sarjana, I. D. G. R. 
2016. Potensi dan Peran Kelembagaan Pertanian dalam Perlindungan Lahan Pertanian Pangan di Provinsi Bali. Jurnal Manajemen Agribisnis. 4 (1) : 1-9.

Suradisastra, K. 2018. Strategi Pemberdayaan Kelembagan Petani. Jurnal Forum Penelitian Agro Ekonomi. 26 (2) : 82-91.

Suswandi dan Sutarno. 2017. Analisa Dinamika dan Kemandirian Kelembagaan Ekonomi Petani dengan Penerapan Pertanian Organik Bersertifikasi di Kabupaten Boyolali. Prosiding Seminar Nasional. 220-240.

Syukur, S. H., Fanani, Z., Nugroho, B. A., and Antara, M. 2014. Empowerment of Livestock Farmer through Graduate Program to Build to Village on Dynamics of Beef Cattle Farmers Groups Level of Gaduhan Model. Journal of Natural Science Research. 4 (2): 107-112.

Wahyuni, D. 2017. Penguatan Kelembagaan Petani Menuju Kesejahteraan Petani. Jurnal Kesejahteraan Sosial. 10 (17) : 9-12.

Wiyono, G. 2011. Merancang Penelitian Bisnis dengan Alat Analisis SPSS $17.0 \quad \&$ SmartPLS 2.0. Unit Penerbit dan Percetakan STIM YKPN Yogyakarta. Indonesia.

Yudiarini, N. 2014. Perubahan Pertanian Subsisten Tradisional ke Pertanian Komersial. Jurnal DwijenAGRO. 2 (1) : 1-8.
Yunita, Riswani, Fitrianti, Y., Hendrixon, dan Murtiaty, N. 2014. Meningkatkan Penguatan Kelembagaan dan Permodalan Petani Lahan Lebak Sumatera Selatan. Prosiding Seminar Nasional Lahan Suboptimal. 482-498. 